\title{
Names of Four Emperors in the Book of Giacomo di Pietro Luccari
}

\section{GEORGE SOTIROFF}

\begin{abstract}
J Iacomo Di PIETRo LuCcari put the finishing touches to his 175page volume, Copioso Ristretto degli Annali di Rausa, in Venice, on December 24, 1604. This patriotic book, written in Italian, praised the city of Ragusa, where Luccari was at home. A second edition of the Ristretto was published in Ragusa, in 1790. However, no more editions appeared after that date and, today, Luccari is practically unknown among historians and linguists. Neither does he seem to be known among students of onomastics.

In his Ristretto, Luccari uses quite a few sources, which have become exceedingly rare during the last 365 years. Some of these sources are actually no longer available. We should not forget that the 30-year war started 14 years after publication of Luccari's book and that it caused terrible losses of life and property including that of many valuable libraries. This makes Luccari's book all the more precious. Since the history of Rausa - or Ragusa, as the name of the city is usually spelled is narrowly linked with that of south-eastern Europe, Luccari could not help discussing persons and events south of the Danube. In so doing, he has preserved for us interesting information not available in sources more easily accessible to present-day scholars. Among other things, he gives the Slavonic equivalents of the names of four Emperors: Probus, Gratian, Justinian, and Justinus. In addition, he gives the Slavonic names of Justinian's father, and that of the father of Maximinus Thrax. A study of these names suggests that latinization may have taken place of them, as well as of names not occurring in Luccari's book. However, for the moment we shall limit ourselves to a cursory examination of names which actually occur in Luccari's Ristretto.
\end{abstract}

\section{(i) Mečko}

In the year A.D. 235 the Thracian legions raised to the imperial dignity Maximinus Thrax. Julius Capitolinus tells us that the father of Maximinus was called Micca, his mother Ababa. ${ }^{1}$ That Ababa is only an aspirated form of the Slavonic word $b a b a$ is virtually certain. How about

\footnotetext{
1 Julius Capitolinus. Maximini Duo. Script. Hist. Aug. (Loeb, t. II, p. 317).
} 
Micca? This could be a truncated form of Micaï, i.e. Michael. However, Luccari, in speaking of a Tartar raid upon the city of Pleuie (Pleven?), south of the Danube, says that it was here that Mečko, the father of emperor Maximinus was born. ${ }^{2}$

\section{(ii) Dobrio}

Another interesting name is that of Dobrio. This, according to Luccari was the Slavonic form of the name Probus, ${ }^{3}$ who was a native of Sirmium (Mitrovitsa), a city in Pannonia where the language of the people was a Thracian dialect. ${ }^{4}$ According to Flavius Vopiscus, the mother of Probus was of nobler birth than his father; his private fortune was modest, and his kindred unimportant. The young man had such bodily strength that Valerian made him a military tribune almost before his beard was grown. All biographers agree that Probus was a most talented and just ruler. $\mathrm{He}$ is said to have combined the virtues of $\mathrm{Au}$ relian, of the Antonines, of Trajan and of Claudius. ${ }^{5}$ Luccari who is likely to have known all this, knew also that the father of Probus was a Pannonian. Probus, who ruled from 375 to 383 , spent practically all his time away from Rome, preparing, as it were, the shift of the capital away from Italy. When Diocletian, who had been an officer in the army of Probus, became emperor, he de facto if not de iure moved the capital of the empire to Nicomedia in the Asiatic part of Thrace, a short distance to the east of the Bosphorus.

\section{(iii) Milutin}

The next interesting case we find in Luccari's book is that of the emperor Gratian. Flavius Gratianus was born at Sirmium, in the year 359. He was the son of Valentinian I, and is known to have been partial to the Alani. In discussing certain events of the thirteenth century, Luccari mentions a Serbian king Milutin. In Italian, says Luccari, this name would be "Gratiano, nome ch'egli rinouò da Gratiano Ungaro Imperadore Romano." "There is, of course, no Hungarian name Gratian, or Milutin. However, knowing that Valentinian I was a Pannonian, we can imagine that the name he gave to his son was exactly the one we find here namely Milutin.

2 Op. cit., p. 104. Note that Mečko could have been a diminutive of Mečislav.

3 Ibid., p. 70.

4 Flavius Vopiscus. Probus. Script. Hist. Aug. (Loeb, t. III, p. 341).

5 Ibid., p. 359.

- Op. cit., p. 37. 


\section{(iv) Uprauda}

Referring to the "libellus" of Doclea, " Luccari mentions the name Istok. This was a Slavonic baron, says Luccari "whose wife's name was Biglenza [sic], a sister of Justinus [sic], ${ }^{8}$ and mother of Justinian, Roman emperors who, as I have seen from a diary in Bulgaria, are called in the Slavonic speech Uprauda, which means Justinian or Justinus." 9 Since Justinus was unquestionably a Thracian, and inasmuch as the Thracians spoke a Slavonic dialect, we may infer that the original name of Justinus was Uprauda. Justinian is, of course, a diminutive form of Justinus.

The name Biglenza occurs also in Procopius, in a Greek form (Bt$\gamma \lambda \varepsilon v \tau^{\prime}(\alpha)$. Procopius says that she was the sister of Justinian. ${ }^{10}$ It is possible, of course, that the daughter had the same name as the mother.

Regarding the name Uprauda, one should mention the fact that another man of the same name (Uprauda Katunar di Dabar) was also known to Luccari, in connection with events which took place around the year 1462.11 It would seem, thus, that the name continued to be used in south-eastern Europe for quite some time.

\section{(v) Istok}

Procopius also says that Justinian's father was called Sabbatius. ${ }^{12}$ A detail of this kind cannot fail to attract the reader's attention, for it is known that Sabazius was the Thracian name of Apollo, whom the Thracians identified with the sun..$^{13}$ On the other hand, Istok in the Slavonic speech means Sunrise, in Latin Oriens, i.e. East.

\section{Conclusions}

Can any conclusion be drawn from this brief survey of names? The importance of Luccari's book resides in the fact that he gives us the original names of four Thracian emperors, as well as the names of three parents of such emperors, names which appear in forms different from their Greek and Roman equivalents. Inasmuch as some of these names appear also in other sources, this makes it possible to do some cross-

7 De Regno Dalmatiae et Croatiae Libri Sex (Amstelodami, 1666).

8 Luccari spells this name Giustiano.

9 Op. cit., p. 3. It should be noted that Mauro Orbini too calls Justinian a Slavonic emperor. (Il Regno degli Slaui. Pesaro. 1601, p. 175.)

10 Vand., IV. XXIV. 3 (Loeb, t. II, p. 416). The English translator, H. B. Dewing, has cheerfully latinized this name to Vigilantia. In the language of Justinian's family Bieleniza means, of course, Blanche.

11 Op cit., p. 109.

12 Anecdota XII. 18 (Loeb, t. VI, p. 150).

13 Macrob., Sat. I. 18. 8-11. 
checking. Among these other sources should be mentioned the interesting booklet of Ivan Tomko Marnavich. ${ }^{14}$ Careful and dispassionate study of Marnavich and some other authors may alter the accepted views on mediaeval civilization. It might not be a bad thing, therefore, if some young scholar were to go over these sources once more, and make them available to modern students.

Luccari's Ristretto deserves greater attention than it has received heretofore, for another reason too. It mentions a great many other significant names of persons and places prominent throughout Central and Southeastern Europe up to the end of the sixteenth century. The configuration of these names differs greatly from the familiar one. It represents thus a challenge to those scholars who may feel the urge to fill some of the gaps with which our textbooks abound.

14 The booklet has been published as part of an article by James Bryce ("Life of Justinian by Theophilus," English Historical Review, II, 1887, p. 657-686). Bryce's desperate attempt to discredit Marnavich is well worth reading.

\section{Université Laval}

\section{ANS ANNUAL MEETING}

The annual meeting of the American Name Society will be held at the Midland Hotel, 172 W. Adams street, Chicago, Illinois, on December 29 and 30, 1971:

Wed., Dec. 29 : 3 p.m. -6 p.m.: Business meetings, Teakwood Room. 7 p.m.: Dinner, Pershing Room.

Thurs., Dec. 30: 9 a.m.-5 p.m.: Program session: reading of papers, sec'y-treasurer's and editor's reports, Board Room. 